\title{
Advantages of applying composite material to replace metal alloys in aviation
}

\author{
Marcelo André Santiago Barros ${ }^{1}$, Roberto Tetsuo Fujiyama ${ }^{1}$, Jandecy Cabral Leite ${ }^{2}$ \\ ${ }^{1}$ Postgraduate Program in Industrial Engineering-PPGEI/Federal University of Pará (UFPA). Augusto Correa Street 01 Guamá. \\ Belém - Pará - Brazil (*marcelo@mbxti.com.brfujiyama@ufpa.br) \\ ${ }^{2}$ Instituto de Tecnologia e Educação Galileo da Amazônia (ITEGAM).(jandecy.cabral@itegam.org.br)
}

\begin{abstract}
Composite materials were already used by man in the early agricultural societies and the expanding use of this material has been driven by technological needs of the military. The high fuel prices and increasingly stringent environmental laws have created a great demand for use of this technology in the civilian sector. The purpose of this article is to show the application advantages of composites in aircraft structures, particularly in reducing weight, reduce operating costs, environmental, social and economic impact. The materials and methods were document and experimental research available in a number of studies and publications, as well as comparisons with similar aircraft composite alloy material and finally the influences in the global economy, with the reduction of freight costs in air transportation and the effects on the whole production chain which is significantly improved.
\end{abstract}

Keywords: Composites, Aircraft and Metal Replacement.

\section{Vantagens da aplicação de materiais compostos para substituir as ligas de metais na aviação}

\section{RESUMO}

Os materiais Compostos já foram usados em sociedades agrícolas e expandir a utilização deste material tem sido impulsionada pelas necessidades tecnológicas das forças armadas. Os altos preços do combustível e regulamentos ambientais cada vez mais rigorosos criaram uma demanda para o uso desta tecnologia no setor civil. O objetivo deste artigo é mostrar as vantagens da aplicação de materiais compósitos em estruturas de aeronaves, particularmente na redução de peso, reduzir custos operacionais,, o impacto social e econômico ambiental. Materiais e métodos eram documento experimental de pesquisa e disponível em um número de estudos e publicações, bem como comparações com o material da liga semelhante aviões compostas e, eventualmente, influencia sobre a economia mundial, com custos de frete reduzidas no transporte aéreo e os efeitos sobre toda a cadeia de produção tem melhorado significativamente.

Palavras Chaves: Compostos, Aeronaves e Metal, Substituição.

The application advantages of composites to replace metal alloys in aviation is treated as a collection of results of studies and applications in a vital sector of society and is the research object of this paper. Because of the complexity, importance and economic integration, several studies come from this important sector, leveraging new structures in the transport area, and contributing to produce everyday applications.

The airline industry has become strategic in the growth of world economies. For [1] the increase and income distribution mainly in emerging countries added a new share in the users of the airlines. The demand of the Brazilian market grew at rates of $5.2 \%$ which is higher than the national PIB. The global air transport carries 2,400 million users per year, including $40 \%$ of international tourism, $35 \%$ of international trade generates about 32 million Jobs as mentioned by [2].

Opposing to these positive results the given high cost of operation of airlines has been a limiting factor in the results of the civil aviation industry. The increasing fuel prices has affected significantly the sector. Fuel accounts for $40 \%$ of the costs of the companies when the world average is about $32 \%$ [3]. Environmental issues have become part of the concerns in the aeronautical industry, where the kerosene used in commercial aviation produces, due to its combustion, a series of products that can deteriorate the air quality, making it dangerous for living beings [4].

To remain competitive and operational, the activities of this sector demand a great number of innovations and technological advances, these changes are driven by the market and also by the 
public sector respecting the environmental and safety standards which creates the need for lower operating costs and environmental performance contained in increasingly strict standards [5].

Innovation is an inherent feature in the aircraft industry, the needs of businesses fall mainly on lower operating costs and improved environmental performance. The key aspects which concentrate the innovative studies are [6]:

Lower aircraft basic weight to increase load capacity for the same counter-attraction amount and burning fuel.

Improves the aircraft aerodynamics to reduce drag and increase the resulting counter-attraction.

Improves the engine performance to reduce fuel burn per effective counter-attraction unit.

The weight reduction studies have opened new fields in the segment of materials. The order to replace metal components using composites has been intensified in the industry in the past decades. With its high degree of reliability, design flexibility and production, as well as its resistance to corrosion, the composite material has become a unique material in various products and equipment [7] [8].

\section{LITERATURE REVIEW}

\subsection{Aeronautical Aluminum}

One of the materials commonly used in aircraft construction, these alloys have characteristics such as high levels of mechanical resistance, low metal density, ease of forming and machining, which makes it ideal for applications in aviation structures.

The main series aircraft aluminum alloys are 2XXX and 7XXX, wherein the first copper alloy is from 1.9 to $6.8 \%$ and usually contain additions of manganese, magnesium and zinc [9].

These alloys have lower crack propagation rate, so the fatigue performance is better than the series 7XXX, and is used in the bottom of the wings and fuselage. The alloys 2224, 2324 and 2524 (modified versions 2224) are composed of $99.34 \%$ pure aluminum for corrosion resistance.

The figure 1 shows the aluminum application in aeronautical structures.

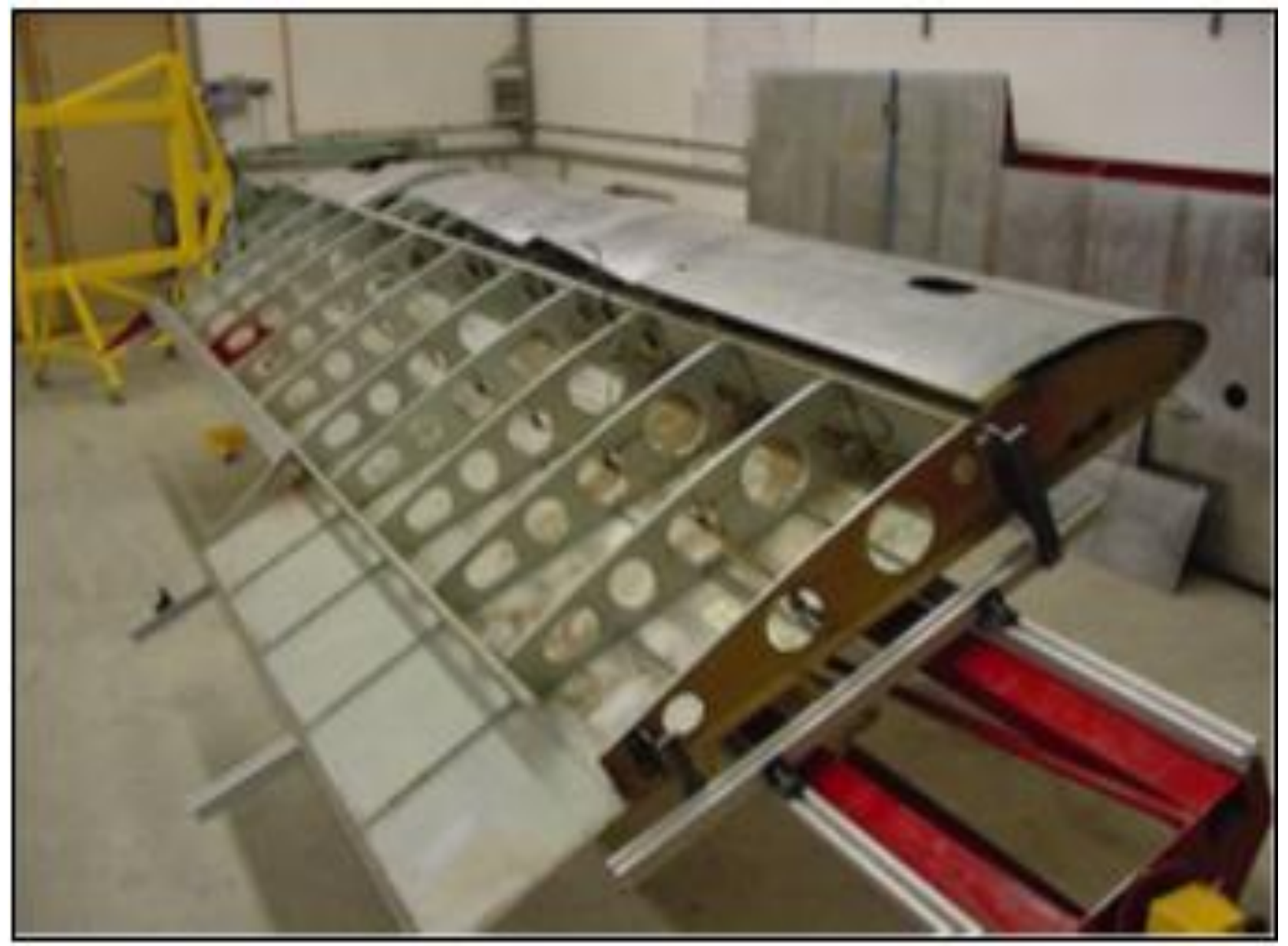

Figure 1 - Aeronautical aluminum application in an aircraft wing

Each has its own characteristics and the ones commonly applied in the aircrafts are presented by the table 1 
Marcelo A. S. Barros ${ }^{1}$, Roberto T. Fujiyama ${ }^{1}$, Jandecy Cabral Leite ${ }^{2}$ / ITEGAM-JETIA Vol.01, Nº 03, pp.19-29. Setembro - 2015

Table 1. Aluminum aloys properties.

\begin{tabular}{|c|c|c|c|c|c|c|}
\hline \multicolumn{7}{|c|}{$\begin{array}{l}\text { ALUMINUM ALLOYS COMPARATIVE TABLE } \\
\text { Alloy Selection Criteria }\end{array}$} \\
\hline \multicolumn{3}{|c|}{$7 \mathbf{X X X}$} & \multicolumn{3}{|c|}{$2 X X X$} & \multirow{2}{*}{$\begin{array}{l}\mathbf{5 X X X} \\
\text { ALUMOLD } 110\end{array}$} \\
\hline & ALUMOLD 500 & ALCAST & $\begin{array}{l}7075 \\
\text { T651 }\end{array}$ & ALUMOLD 350 & $\begin{array}{l}2024 \\
\mathrm{~T} 351\end{array}$ & \\
\hline Yield Strength & $470-540 \mathrm{MPa}$ & $280 \mathrm{MPa}$ & $260-470 \mathrm{MPa}$ & $330-366 \mathrm{MPa}$ & $290 \mathrm{MPa}$ & $110 \mathrm{MPa}$ \\
\hline Resistance Limits & $510-590 \mathrm{MPa}$ & $310 \mathrm{MPa}$ & $360-540 \mathrm{MPa}$ & $420-465 \mathrm{MPa}$ & $430 \mathrm{MPa}$ & $240 \mathrm{MPa}$ \\
\hline $\begin{array}{l}\text { Thermal } \\
\text { Conductivity }\end{array}$ & $153 \mathrm{Wm} \mathrm{C}$ & $150 \mathrm{Wm} \mathrm{C}$ & $134 \mathrm{Wm} \mathrm{C}$ & $130 \mathrm{Wm} \mathrm{C}$ & $121 \mathrm{Wm} \mathrm{C}$ & $117 \mathrm{Wm} \mathrm{C}$ \\
\hline Extension & $1,5 \%$ A $10 \%$ & $1,5 \%$ & $2 \%$ a $6 \%$ & $4 \%$ A $9 \%$ & $11 \%$ & $9 \%$ \\
\hline $\begin{array}{l}\text { Elasticity } \\
\text { Modulus }\end{array}$ & $72.000 \mathrm{Mpa}$ & $72.000 \mathrm{Mpa}$ & $72.000 \mathrm{Mpa}$ & $72.4000 \mathrm{Mpa}$ & $73.1000 \mathrm{Mpa}$ & $71.100 \mathrm{MPa}$ \\
\hline $\begin{array}{l}\text { Brineli } \\
\text { Hardness }\end{array}$ & $175-185 \mathrm{HB}$ & $135 \mathrm{HB}$ & 104-161 HB & $135-145 \mathrm{HB}$ & $120 \mathrm{HB}$ & $80 \mathrm{HB}$ \\
\hline Machinability & Extraordinary & Excellent & Good & Great & Good & Good \\
\hline $\begin{array}{l}\text { Dimensional } \\
\text { Stability }\end{array}$ & Excellent & Extraordinary & Great & Excellent & Good & Excellent \\
\hline Polishability & Excellent & Good & Not Suitable & Good & Not Suitable & Not Suitable \\
\hline Soldability & $\begin{array}{l}\text { Possible for } \\
\text { Repairs }\end{array}$ & $\begin{array}{l}\text { Possible for } \\
\text { Repairs }\end{array}$ & $\begin{array}{l}\text { Possible for } \\
\text { Repairs }\end{array}$ & $\begin{array}{l}\text { Possible for } \\
\text { Repairs }\end{array}$ & $\begin{array}{l}\text { Possible for } \\
\text { Repairs }\end{array}$ & Excellent \\
\hline $\begin{array}{l}\text { Corrosion } \\
\text { Resistance }\end{array}$ & Not Suitable & Not Suitable & Not Suitable & Not Suitable & Not Suitable & Excellent \\
\hline
\end{tabular}

\subsection{Composite Materials in the Aeronautical Industry}

The composites adoption for aircraft industry began with the experimental and military aviation and then in the commercial and business aviation. In general it is almost commonplace that the composites are the latest technology for aeronautical use, for bringing together key features to the sector [11]:

Less aluminum alloys relative weight due to higher specific stiffness and specific strength;

The material mechanical properties can be increased toward the larger effort suffered by the part;

Corrosion absence in case of high humidity or high incidence of sea air environments exposure;

Excellent fatigue resistance and dimensional stability. To really take advantage of these properties, it is essential to study these materials and develop projects to analyze its features, otherwise the results may be worse than traditional materials.
Despite the many advantages, the composites have weak points and limits, failure modes are less predictable than metallic materials

A crack aluminum is relatively straightforward and can be detected visually or with non-destructive methods different from carbon fiber composites which does not present cracks and fatigue effects [12].

\subsection{Composite Materials Architecture.}

Composite materials consist of at least two components (as shown in Figure 2) or two phases, with distinct physical and chemical properties in the composition. Separated component retains its characteristics but when mixed forms different compounds with completely different chemical and mechanical properties

\section{Reinforcement} Arrangement

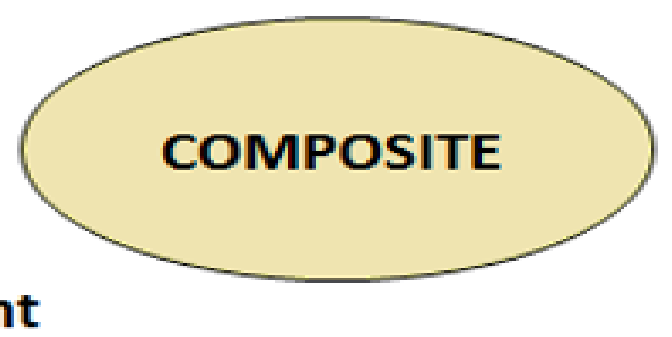

Figure 2 - Composite Material Structure. 
Marcelo A. S. Barros ${ }^{1}$, Roberto T. Fujiyama ${ }^{1}$, Jandecy Cabral Leite ${ }^{2}$ / ITEGAM-JETIA Vol.01, Nº 03, pp.19-29. Setembro - 2015 Composite materials are commonly produced in Laminated unidirectional fibers (Figure 3, letter a) has laminated layers of fabric, ribbon or filament bundles a particular strength in relation to the longitudinal with extremely small thickness and are stacked to fibers and in the perpendicular direction the resistance form something like a thicker layer. The composites is much lower.

can be shaped as three-dimensional solid body [13].

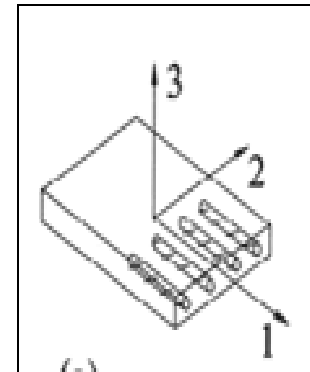

(a)

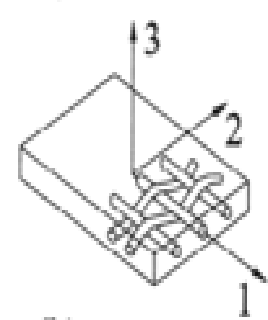

(b)
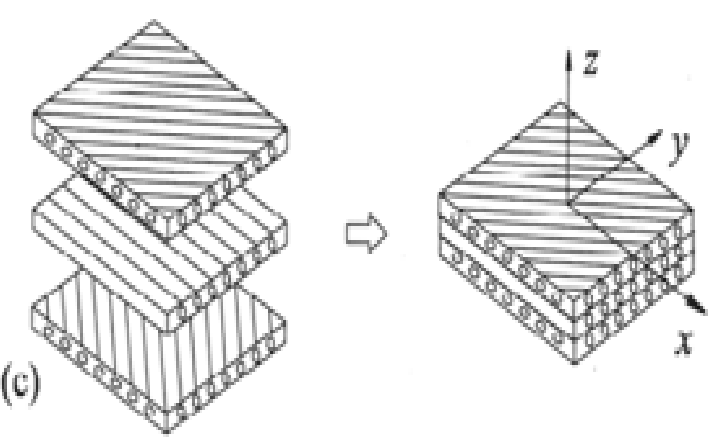

Figure 3 - (a) unidirectional fibers sheet; (b) woven fibers sheet; (c) laminate consisting of several sheets oriented in different directions [13].

\subsection{Composite Materials Applied in the} Aeronautical Industry.

Carbon fibers, glass fibers and aramid fiber composites are the most widely used in aviation, presenting advantages and also negative factors [12].

\subsubsection{Carbon Fibers}

It is a synthetic fiber made from carbonaceous materials that can be natural (with carbon poor performance not being used in structures requiring strain), or polyacrylonitrile synthetic (high yield on carbon) fiber known as "PAN"

(from Polymer acrylic nitrile).

The fibers may be manufactured in many specifications: but only the most expensive, rigid and resistant present the properties to use in aeronautical structures [14].

The table 2 presents carbon fibers resistance properties

Table 2 - Nominal Properties of the Carbon/Epoxy Composite F 584

\begin{tabular}{|c|c|c|c|}
\hline Mechanical Properties & $\begin{array}{l}\text { Unidirectional } \\
\text { Tapes }\end{array}$ & $\begin{array}{l}\text { Bidirectional } \\
\text { Fabric }\end{array}$ & $\begin{array}{l}\text { ASTM } \\
\text { Standard }\end{array}$ \\
\hline Longitudinal Module, $\mathrm{E}_{1}(\mathrm{Gpa})$ & 130 & 65 & D 3039 \\
\hline Cross-Section Module, $\mathrm{E}_{2}(\mathrm{Gpa})$ & 2 & 65 & D 3039 \\
\hline Shearing Module, $\mathrm{G}_{12}(\mathrm{Gpa})$ & 6 & 5 & D 4255 \\
\hline Poisson Quotient, $\mathrm{V}_{12}(\mathrm{Gpa})$ & 0,27 & 0,05 & D 3039 \\
\hline Longitudinal Traction Resistance, $\mathrm{X}_{\mathrm{T}}(\mathrm{MPa})$ & 1721 & 680 & D 3039 \\
\hline Transversal Traction Resistance, $\mathrm{Y}_{1}(\mathrm{MPa})$ & 43 & 680 & D 3039 \\
\hline Longitudinal Compression Resistance, $\mathrm{X}_{\mathrm{e}}(\mathrm{MPa})$ & 703 & 548 & D 3410 \\
\hline Transversal Compression Resistance, $\mathrm{Y}_{\mathrm{e}}(\mathrm{MPa})$ & 133 & 548 & D 3410 \\
\hline Plane Cross-Section Resistance, $\mathrm{S}_{12}(\mathrm{MPa})$ & 88 & 122 & D 4255 \\
\hline Interlaminated Cross-Section Resistance, $\mathrm{S}_{13}(\mathrm{MPa})$ & 84 & 70 & D 2344 \\
\hline Specific Mass, $\mathrm{p}\left(\mathrm{kg} / \mathrm{mm}^{3} \times 10^{-5}\right)$ & 0,155 & 0,157 & D 3171 \\
\hline Layer Nominal Thickness, $\mathrm{t}_{\text {nom }}(\mathrm{mm})$ & 0,18 & 0,35 & - \\
\hline Resin Specific Mass $\left(\mathrm{g} / \mathrm{cm}^{3}\right)$ & 1,22 & 1,22 & - \\
\hline Carbon Fiber Specific Mass $\left(\mathrm{g} / \mathrm{cm}^{3}\right)$ & 1,77 & 1,77 & - \\
\hline
\end{tabular}

Source: [11]. 


\subsubsection{Glass Fiber}

Widely used in the aircraft industry since the 60 s, the silicon dioxide $(\mathrm{SiO} 2)$ raw material associated with other oxides, distinguished basically the "E-glass" and the "S-glass" with elastic modulus and different specific strength. The "E" refers to the "electric", as they have

\subsubsection{Aramid Fiber (Kevlar)}

One of the most important features is its extreme resistance to shear that is derived from an aromatic polyamide (thermoplastic polymer composed by amide monomers) with similar construction process of the glass fiber. more resistance to electrical conductivity than the fibers "S being more used in aircraft structures. Generally, the glass fibe: are less resistant than the carbon fibers with lower elasticil module and are unsuitable for structures requiring stiffness [14]

These fibers are lightweight and have a lower tensile strengtt than carbon fiber, but higher than aluminum [14].

The figure 4 shows the main fibers applied at aeronautica industry.

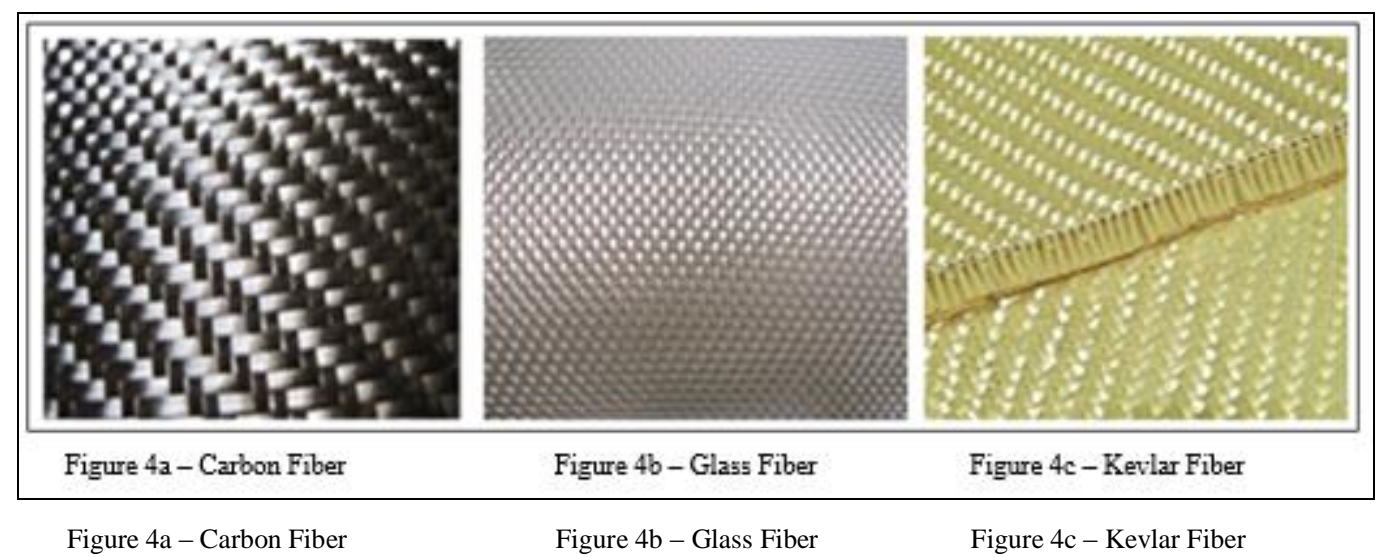

The required properties of an aircraft component depend on the area where it is installed, the resistance is useful in areas that experience large load as wings, at a moderate load as the nose of the airplane, the stiffness is the main property.

Despite being in use for a long time in military aviation, there was a resistance in the use of carbon fiber in commercial aircraft, mainly due to the difficulty to determine the material fatigue. The figure 5 shows a comparison of mechanical properties of the steel, aluminum and titanium composites, commonly used in the aircraft industry.
2.5 Replacement of the aluminum materials by the composite materials in the aeronautical industry.

Airbus in Europe and the US Boeing aircraft manufacturers are leading the use of composite materials to replace metal alloys [15].

The safety requirement levels in the aviation industry reach almost $100 \%$ because the materials employed that make up th structures should support continued efforts and possess hig strength, fatigue and corrosion values.

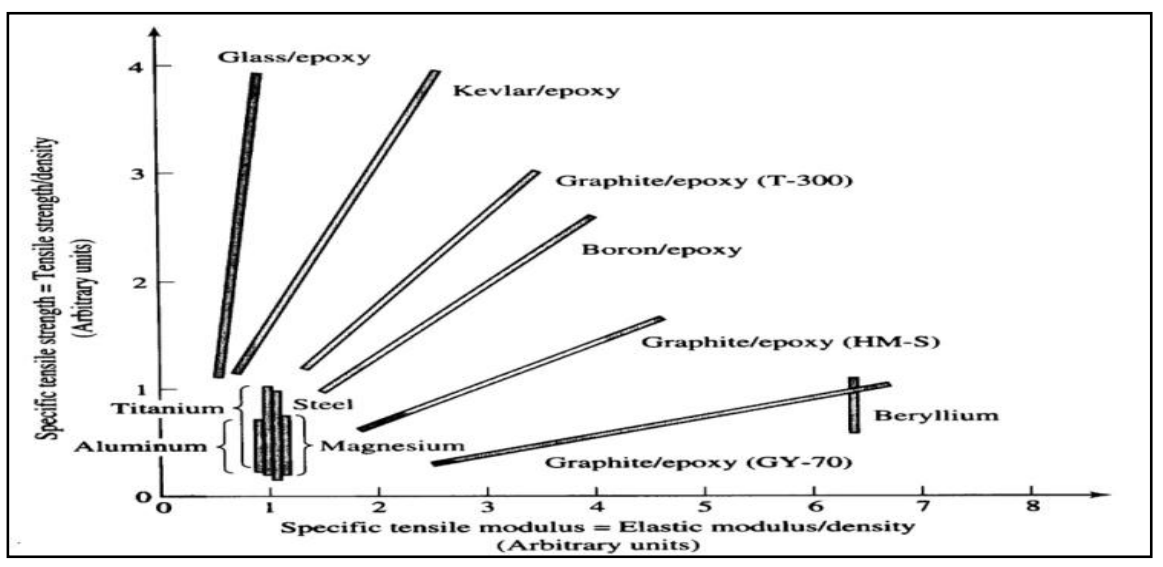

Figure 5 - Composite Material Performance.Source: [23]. 
Marcelo A. S. Barros ${ }^{1}$, Roberto T. Fujiyama ${ }^{1}$, Jandecy Cabral Leite ${ }^{2}$ / ITEGAM-JETIA Vol.01, Nº 03, pp.19-29. Setembro - 2015

As an example of large-scale use of composites, the new composites, the fuselage is made entirely of Carbon Fiber generation Airbus aircraft brings together the latest in Reinforced Plastic (CFRP) reducing fuel consumption and aerodynamics, design and technology. In the A350XWB, improve the maintenance [15]. The figure 6 presents the more than $70 \%$ of the structures weight are made of material proportion used at the A350XWB aircraft. composite, titanium and aluminum

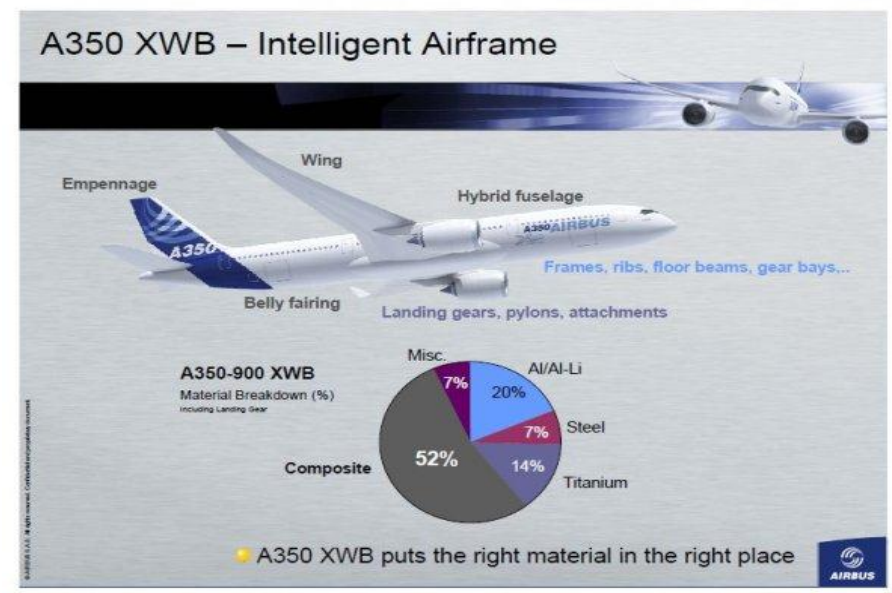

Figure 6 - Used Materials in the A350XWB Aircraft. Source: [24].

The use of composite plastic materials reinforced with CFRP fiber has increased significantly in civil aviation in the last years especially in more modern aircraft such as the A350 and Boeing 787 Aibus [16]. The figure 7 displays the increasing use of the CFRP in the aviation industry.

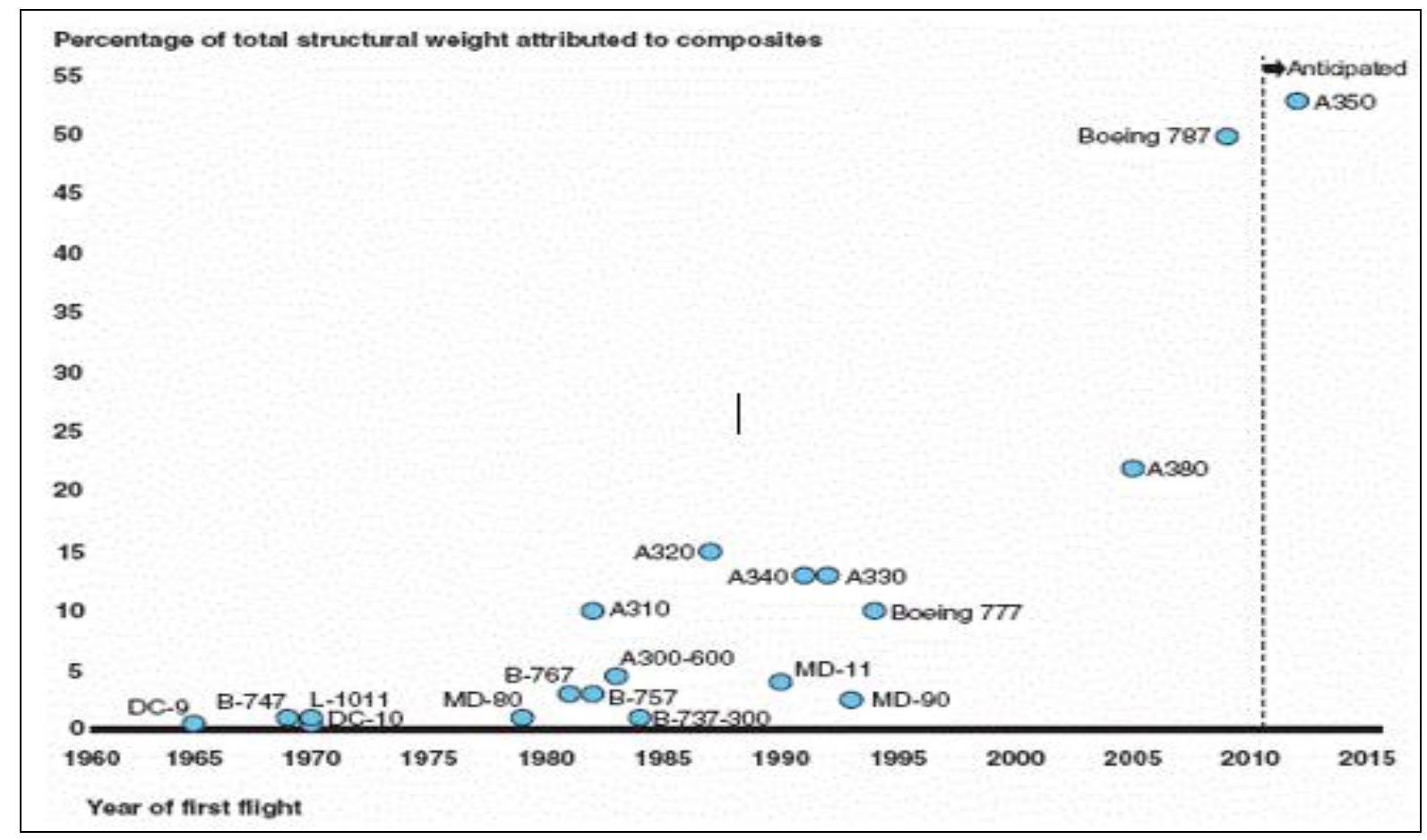

Figure 7 - Aircraft CFRP.Source: [21]. 
In military aviation, the use of more advanced composite researches of smaller pieces [15]. The figure 8 displays the materials is mainly due to less stringent security requirements, composite materials application in the military aviation. larger amount of funds made available by the government for military

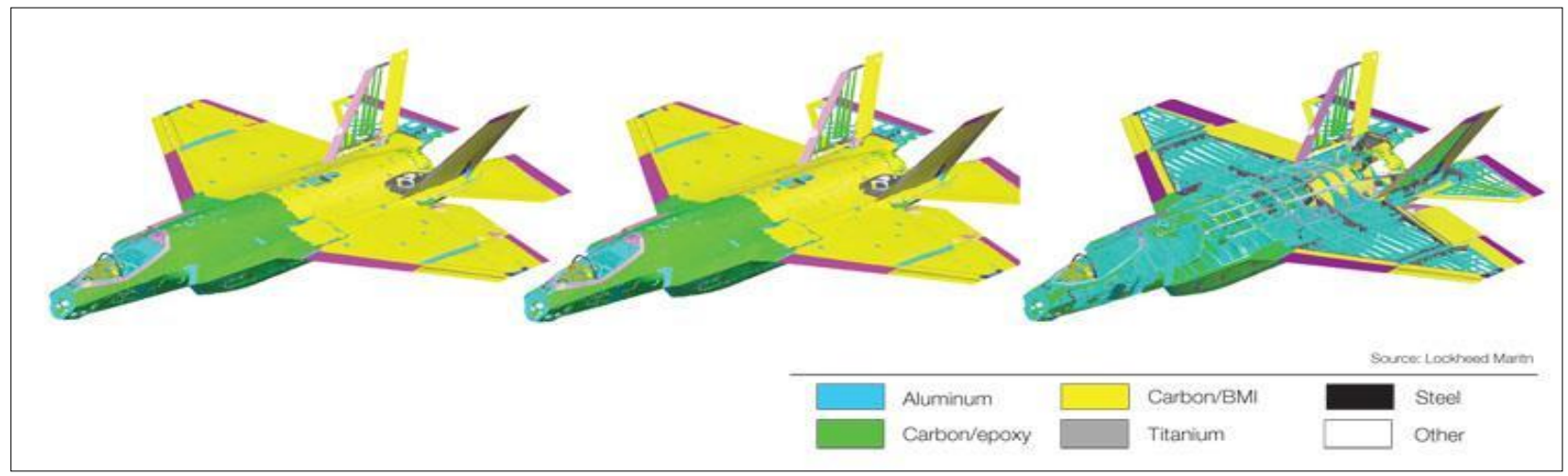

Figure 8 - Composite Material Percentage applied in the Military Aircrafts. Source:[23].

In the figure 9 is possible the compare the structural weights of the composite and aluminum fuselage.

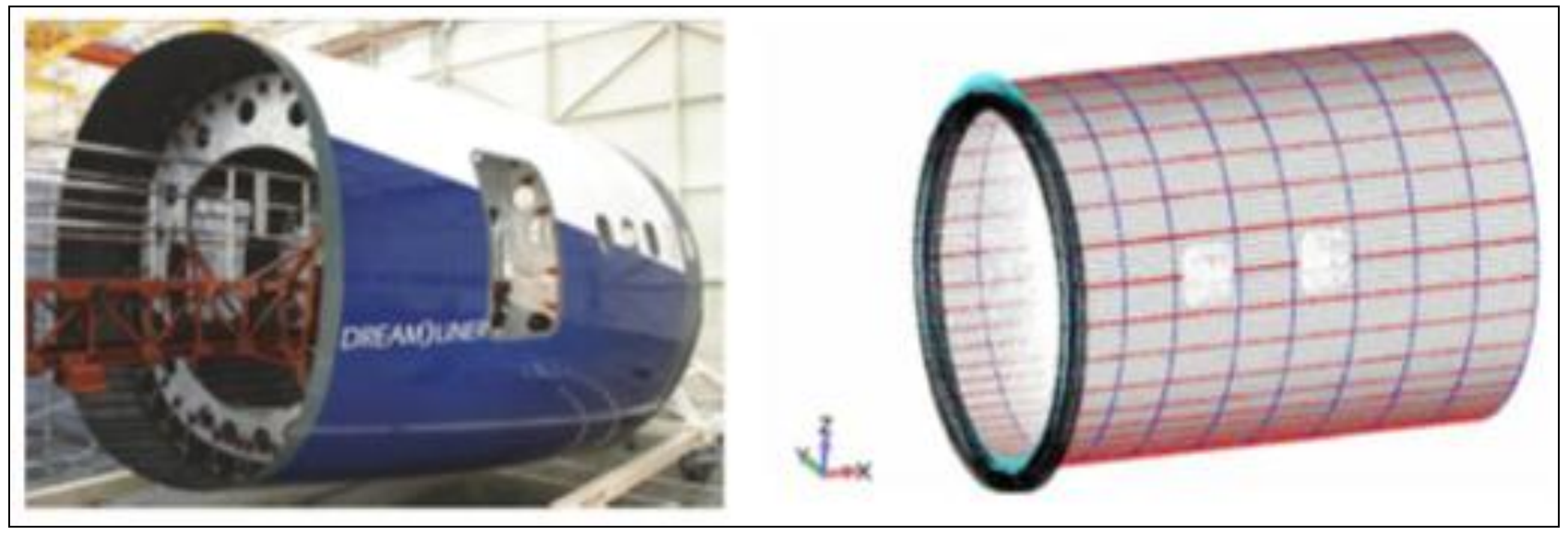

Figure 9 - Simplified structure section for comparative calculation.

To make the comparative analysis of the composite and aluminum fuselage weights the material volume used in a section with reduced dimentions from the external structure were used. The data used for these calculations are presented bellow:

Specific mass of the carbono/epoxy composite fiber: $1,57 \mathrm{~kg} / \mathrm{m}^{3}$ Al 2024 alloy specific mass: $2,78 \mathrm{Kg} / \mathrm{m}^{3}$

Section length: $6 \mathrm{~m}$

Material Thickness: 0,03 m

Fuselage ray: $1 \mathrm{~m}$

Aproximated Fuselage Volume:

$\mathrm{V}=\pi \cdot h \cdot \mathrm{r}(2 \mathrm{R}-\mathrm{e})$

Aproximated Fuselage Weight:

$\mathrm{P}=\rho . \mathrm{V}$
Aluminum Section Volume Calculation.

.6. $(0,03) .(2-0,03)$

$\mathrm{V}=1,11 \mathrm{~m}^{3}$

$\mathrm{V}=3,14$

Aluminum Section Weight Calculation and Composite Section Weight Calculation:

$$
\begin{aligned}
& \mathrm{P}=1,11 \times 2,78 \\
& \mathrm{P}=1,11 \times 1,57 \\
& \mathrm{P}=3,09 \mathrm{kgf} \\
& \mathrm{P}=1,74 \mathrm{kgf}
\end{aligned}
$$

The figure 10 shows the structural comparison between the weights of the two fuselage sections of the study, it was observed that the composite structure has a weight of 56.3\% below the aluminum frame. 


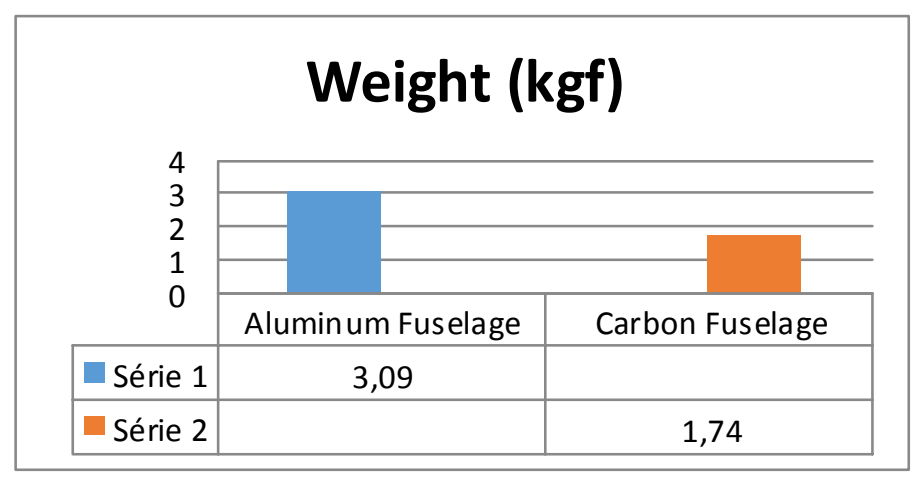

Figure 10 - Comparative analysis of the fuselage structural weights.

Note that for comparison was used only one of the main structural components, this relationship changes when the weight and many other components are included such as: brackets, reinforcement, coating, rivets and etc.

\section{Materiais e Métodos}

To corroborate the information in this article, we used a documentary, literature and experimental research strategy.

The preparation of this work started with the location of texts from various sources available, without regard to the analysis. The objective was to obtain information arising from: internet, scientific

articles bases, official texts and aircraft technical manuals, highlighting the filing of documentation and annotation of origin.

At this stage it were selected two aircraft with similar projects for comparison: Super Petrel (figure 11) of Edra Aeronautics and Corsair Mk III Microleve Industry Ltda vendors. The table 4 shows the technical data of the selected aircrafts.

Table 4. Technical bulletin of Corsário and Super Petrel

\begin{tabular}{|l|l|l|}
\hline \multicolumn{1}{|c|}{ Aircraft } & Corsário & Super Petrel \\
\hline Spread & $10.3 \mathrm{~m}$ & $8,9 \mathrm{~m}$ \\
\hline Wing Area & $16.49 \mathrm{~m}^{2}$ & $15 \mathrm{~m}^{2}$ \\
\hline Length & $6.8 \mathrm{~m}$ & $6,35 \mathrm{~m}$ \\
\hline Maximum Weight & $500 \mathrm{Kg}$ & $600 \mathrm{Kg}$ \\
\hline Empty Weight & $345 \mathrm{Kg}$ & $350 \mathrm{Kg}$ \\
\hline Fuel Capacity & $65 \mathrm{lts}$ & $95 \mathrm{lts}$ \\
\hline Seats & 2 & 2 \\
\hline Range & $410 \mathrm{Km}$ & $600 \mathrm{Km}$ \\
\hline Take off Distance & $79 \mathrm{~m}$ & $80 \mathrm{~m}$ \\
\hline Landing Distance & $67 \mathrm{~m}$ & $120 \mathrm{~m}$ \\
\hline Maximum Velocity & $160 \mathrm{~km} / \mathrm{h}$ & $200 \mathrm{~km} / \mathrm{h}$ \\
\hline Cruise Velocity & $120 \mathrm{Km} / \mathrm{h}$ & $180 \mathrm{~km} / \mathrm{h}$ \\
\hline VelocStall & $48 \mathrm{Km} / \mathrm{h}$ & $65 \mathrm{Km} / \mathrm{h}$ \\
\hline Roof Service & $10.000 \mathrm{ft}$ & $12.000 \mathrm{ft}$ \\
\hline Power & $100 \mathrm{HP}$ & $100 \mathrm{HP}$ \\
\hline Rising & $800 \mathrm{Fpm}$ & $1000 \mathrm{Fpm}$ \\
\hline Vendor & Microleve & Edra \\
\hline
\end{tabular}

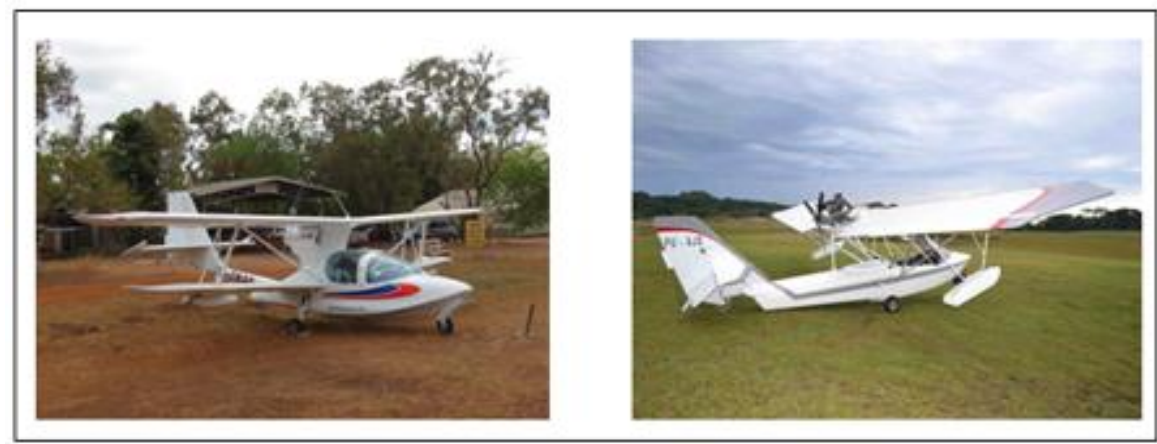

Figure 11. Super Petrel (Composite) and Corsário (Aluminum). 
The Super Petrel and the Corsario aircraft were supplied with 30 liters of jet fuel departing from Amazonas Flying Club in 30 minutes flights to Ponta Negra beach in Manaus Amazonas in order to collect the data. The table 5 shows the collected data.

Table 5 - Data collected during the experimental flight

\begin{tabular}{|l||l||l||}
\hline Aircrat & Corsário & Petrel \\
\hline \hline Mean Velocity & $122 \mathrm{Km} / \mathrm{h}$ & $165 \mathrm{Km} / \mathrm{h}$ \\
\hline \hline Take off & $90 \mathrm{~m}$ & $120 \mathrm{~m}$ \\
\hline \hline Landing & $112 \mathrm{~m}$ & $140 \mathrm{~m}$ \\
\hline \hline Pilot Weight & $90 \mathrm{Kg}$ & $90 \mathrm{Kg}$ \\
\hline \hline Fuel & 30 litros & 30 Litros \\
\hline
\end{tabular}

\subsection{Collected Material Organization}

In the documentary analysis phase we use the organization in a logical structure based on the first applications, the evolution and the current technological state of the use of the material covered, all documents were filed in folders divided chronologically as well as the type of document: articles, manuals, thesis, course completion work, publications and internet. Using qualitative content analysis, we selected the texts from the context of the actual benefits, classifying them into categories that informed the theories exposed in this article. At this stage we made several reading and rereading for the investigation and across the studies the increasing knowledge about various documents have been reclassified in the relevant studies. The flight test data were used for comparison of improved aircraft primarily on the use of composite material.

\section{Results and Discussion 4.1 Experimental flight results.}

In simple analysis, we can notice a higher performance of the Super Petrel aircraft manufactured in composite material, the fastest speed achieved on $20 \%$ average is shown in Table 5, together with the possibility of also higher load, suggests a lower cost per km flown, allowing cover larger distances in less flight time.

4.2 Impact of reducing the weight of aircraft on the environment, aviation and global warming.

Air transport is a sector that contributes with low indexes of $\mathrm{CO}_{2}$ emissions which are around (2\%), however according to the Intergovernmental Panel on Climate Change [4] these are more harmful compared to other relatively sources. This is because the waste released by aircraft increase the effects of carbon dioxide due to high altitudes (troposfere lower stratosphere high), falling directly on the concentration of greenhouse phases, intensifying the phenomenon of global warming. For this reason in 2006 has launched up a joint technology action named Clean Sky (Clear),
Sky (Clear), which brings together 86 organizations from 16 countries, 54 companies, 15 research centers and 17 universities, in order to develop emission reduction initiatives of $\mathrm{CO}_{2}$ by $50 \%$ until 2020 [17].

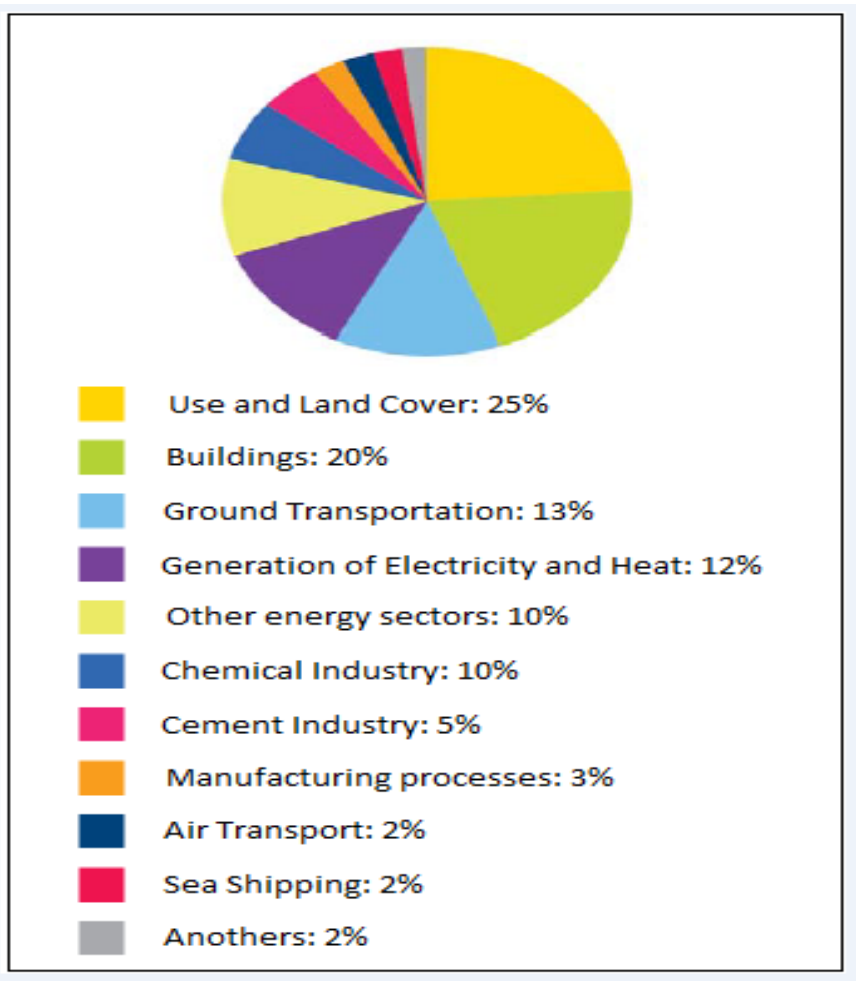

The figure 12 shows the global $\mathrm{CO}_{2}$ emitions.

Source: [25].

The weight of an aircraft is a significant variable in operations, in a flight of long range daily made for example, every pound of unnecessary weight may amount in a consumption of up to 200 liters of aviation kerosene (jet fuel) after one year of operation, over the same period a small sugar sachet would comsume around 15 liters [18] [19]. This sensitivity shows the importance of aircraft weight reduction, with a lower consumption of fuel and reduction of $\mathrm{CO}_{2}$ emissions.

The fuel consumption of a passenger aircraft may be expressed, according to a study done in [20] by the following equation (3):

$C=C e \cdot \frac{P}{n \cdot v m \cdot F c}$

$C=$ consumed/seat fuel $] x[\mathrm{Km}]$

$C_{e}=$ aircraft specific comsume (comsumed $\mathrm{Kg}$ per hour)

$P=$ aircraft free weight $(\mathrm{Kg})$

$n=$ number of seats

$v_{m}=$ average flight velocity $(\mathrm{Km} / \mathrm{hour})$

$F_{c}=$ load factor

According to the above equation, a reduction in aircraft free weight induces a proportional reduction in fuel consumption 
Marcelo A. S. Barros ${ }^{1}$, Roberto T. Fujiyama ${ }^{1}$, Jandecy Cabral Leite ${ }^{2}$ / ITEGAM-JETIA Vol.01, Nº 03, pp.19-29. Setembro - 2015

\subsection{Weight reduction impact of the aircraft in infrastructure projects in the airports facilities.}

The aircraft passengers capability, cargo and fuel weight, influence the size and the provisions of passenger and cargo facilities, and fuel storage methods, icing chemicals, chemical fire containment, material for track maintenance and etc. The waste from operation of these chemicals can contaminate the soil around exposing humans to hazardous health issues [20]. The heavier the aircraft is the larger is the distance required for takeoff and landing, which impacts the needs of land, access, boundaries escape and neighborhood areas. The weight also influences the type of necessary paving increasing or decreasing construction costs [21]. The figure 13 shows a standard airport runway.

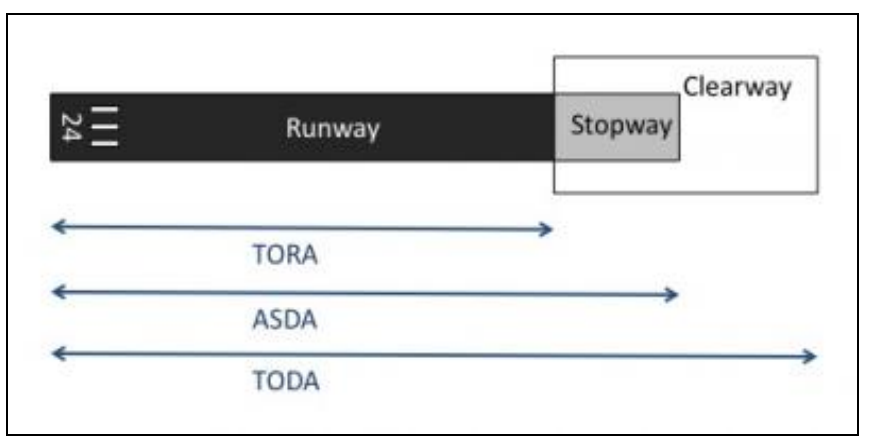

Figure 13 - Airport runway.

Source: [26].

Every plane has a classification number expressing the relative effect of the mass of the aircraft on a deck. $1 \mathrm{ACN}$ is the mass of $500 \mathrm{~kg}$ which is supported by a single wheel with tire pressure of $1.25 \mathrm{MPa}(181,25 \mathrm{psi})$. This is just one example of the aircraft weight influence in the airport infrastructure projects.

\subsection{Weight reduction impact of aircraft fuel consumption and its operational costs}

The price increases of oil derivatives has been the great engine of research to decrease the weight of the aircraft, according to studies conducted by [22], fuel consumption is the second largest component of operating direct costs for airlines, after the costs related to labor. Estimated dry the participation of fuel consumption is in the range of $20 \%$ to $40 \%$ of total operating costs in direct airlines.

The fuel expense is affected by a series of external factors management of a company, such as congestion at the time of takeoff, slopes release delays, retention time for additional etc.Pesos taxiing an aircraft imposes requirements that need to be taken into account in each section traveled on a plane, becoming umfator essential control to the financial health of umaempresa air, influencing in all areas of costs and operation.

\section{Conclution}

This article demonstrates the advances and advantages in using the composite materials in the aerospace industry and their influence in everyday life. Using a set of literature and research in the area of materials and aeronautics, sources from the manufacturers, regulatory agencies, government bodies, environmental institutes and an extensive list of articles on similar topics, has clearly established the great importance of the new composite technologies in cargo and passengers way of transportation. The empirical work reviewed the weight reduction in data structures, the efficiency and performance, with direct influence on air transport freight loads values, reflecting the price of products on world markets. The reduction in major airports needs with long runways, reduces pressure on the areas around the aerodrome by doing so the weight is decreased and the fuel consumption is optimized to mitigate impacts on the atmosphere and the soil around the airports. Innovations has enhanced the aircraft characteristics such as: passenger capacity, flight range, quieter aircraft, comfort, safety, greater performance and decreased travel time between airports in the world. In a more futuristic look, the applications expansion of the composites in increasingly complex structures requires a huge effort in research and development work which stimulates the formation of highly skilled human resources to meet the requirements of lighter weight, strength and corrosion in a new range of products from various sectors.

\section{Acknowledgement}

This research was supported by the Federal University of Pará (UFPA) in partnership with the, Galileo Technology Institute (ITEGAM) and Amazons aeroclube.

\section{REFERENCES}

[1] ANAC (2013). Agência Nacional de Aviação Civil. Disponível em: <http://www.anac.gov.br/>.Acesso em: 02 abr 2014

[2] ATAC. Air Transport Action Group. Disponível em: <http://www.atag.org/>. Acesso em: 17 jan 2014

[3] Sindicato Nacional das Empresas Aeroviárias (SNEA). http://snea.com.br/estudos Acesso em: 10 maio 2014.

[4] IPCC (1999) Intergovernmental Panel on Climate Change. Aviation and the Global Atmosphere.Disponível em: www.ipcc.ch/pdf/special-reports/spm/av-en.pdf. Acesso em: 02 abr 2014

[5] CONAMA - Comisión Nacional Del Medio Ambiente. Disponível em http://www.conama.cl/portal/1301/channel.html Acesso em: 02 agosto 2014. 
Marcelo A. S. Barros ${ }^{1}$, Roberto T. Fujiyama ${ }^{1}$, Jandecy Cabral Leite ${ }^{2}$ / ITEGAM-JETIA Vol.01, Nº 03, pp.19-29. Setembro - 2015

[6] OCDE. Science, Technology and Industrial Outlook, 2008.

[7] HEMAIS, C. A., Polímeros e a Indústria Automobilística. Polímeros: Ciência e Tecnologia, v.13, n.2, p. 107-114, 2003.

[8] SUDDELl, B. C., EVANS, W. J., ISAAC, D. H., CROSKY, A., A survey into the application of natural fibre composites in the automotive industry. Natural PolymersandComposites, 4, 2002, São Paulo. Anais...São Paulo, 2002. p. 455-460.

[9] Associação Brasileira do Alumínio. 2014.

http://www.abal.org.br/aluminio/caracteristicas-quimicase-fisicas/ligas/ligas-de-aluminio-trabalhaveis/2014.

[10] Schmolz Bickenbach do Brasil Ind. e Com. Aço, Ltda. http://www.schmolz-bickenbach.com.br/produtos/ligas-dealuminio/

[11] Polímeros: Ciência e Tecnologia, vol 10, nº 2, 2000.

[12] Baker, Alan; Dutton, Stuart; Kelly, Donald. Composite Materials for Aircraft Structures.Second Edition. AIAA Education Series. Reston, Virginia, 2004

[13] MENDONCA, P.T.R. Materiais Compostos e Estruturas Sanduíche: Projeto e Análise, Editora Manole, 1 ed., Barueri 2005.

[14] ZANATTA, Rodrigo; MATERIAIS compósitos na aviação. Disponível em: http://www.aviacao.org/especiais/materiais-compositos

Acesso em: 02 jun 2014

[15] EADS - European Aeronautic Defence and Space. Disponível em http://airbusdefanceandspace.com/

[16] EHINGER, C; HOFFMANN, A; REIF, W; REINHART, G; STRASSER, G. Automated cutting and handling of carbon fiber fabrics in aerospace industries. 6th IEEE International Conference on Automation Science and Engineering, CASE 2010, p.861-866, Toronto, Canada, August 2010.

[17] Clean Sky (2009) About Clean Sky. Disponível em: www.cleansky.eu/index.php?arbo_id=35.

[18] Boeing, 2003, www.boeing.com.

[19] KLOTZEL, E., 2003, Avião mais leve é meio caminho andado, www.icarobrasil.com.br

[20] GREENE, D. L., 1995, "Commercial air transport
[21] FAA Aerospace Forecasts 2011-2031. Disponível em: http://www.faa.gov/about/office_org/headquarters_offices/apl/aviation _forecasts/aerospace_forecasts/2011-2031/

[22] IATA (2008) International Air Transport Association Building Greener Future. $3^{a}$ edição, Suíça.

[23] Composites World. http://www.compositesworld.com/articles/resins-for-the-hot-zonepart-ii-bmis-ces-benzoxazines-and-phthalonitriles

[24] Mudabahaya Wordpress. http://mudabahaya.wordpress.com/2014/03/05/airbus-a350-xwbcertification-program/

[25] International Maritime Organization. http://www.imo.org/

[26] Skybrary Aero.http://www.skybrary.aero/index.php/Main_Page.

[27] Skone, Timothy J., and Kristin Gerdes. "Development of Baseline Data and Analysis of Life Cycle Greenhouse Gas Emissions of Petroleum-Based Fuels."US Department of Energy, National Energy Technology Laboratory, Office of Systems, Analysis and Planning.November 26, 2008. http://www.netl.doe.gov/energyanalyses/pubs/NETL\%20LCA\%20Petroleum-

Based\%20Fuels\%20Nov\%202008.pdf. 